\title{
The antiangiogenic activities of ethanolic crude extracts of four Salvia species
}

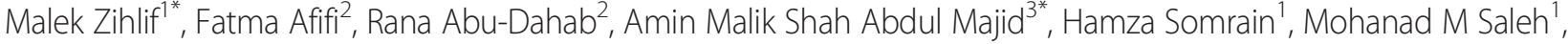 \\ Zeyad D Nassar ${ }^{3,4}$ and Randa Naffa ${ }^{5}$
}

\begin{abstract}
Background: Angiogenesis is one of cancer hallmarks that are required for both cancer progression and metastasis. In this study we examined the antiangiogenic properties of the ethanolic crude extracts of four Salvia species grown in Jordan.

Methods: The direct antiangiogenic activity was evaluated using various models: ex vivo rat aortic ring assay, in vitro assessment of HUVEC proliferation and migration, and in vivo CAM assay, while we used the changes in the expression of HIF-1a and VEGF in breast cancer cells (MCF 7) as an indicative for the indirect antiangiogenic activity.

Results: All four crude extracts showed a potential antiangiogenic activity in the rat aortic assay, however two species were found to be cytotoxic against Fibroblast cell line (PLF); the finding that caused the exclusion of these two extracts from further studies. Of the two remaining extracts, S. triloba showed very promising direct and indirect antiangiogenic activities. S. triloba inhibited the HUVEC proliferation with an $\mathrm{IC}_{50}$ of $90 \mu \mathrm{g} / \mathrm{mL}$ and HUVEC migration by $82 \%$ at $150 \mu \mathrm{g} / \mathrm{mL}$. Furthermore, the in vivo CAM assay also illustrated the high impact of S. triloba against the newly formed vessel in the chicken embryonic membrane. Interestingly, the $S$. triloba inhibited the expression of VEGF at the mRNA and protein and the HIF-1a mRNA in the MCF 7 breast cancer cells under both normoxic and hypoxic conditions.
\end{abstract}

Conclusions: Taken together, all these findings of the direct and indirect angiogenic investigations nominated S. triloba as a highly potent antiangiogenic plant that may have chemotherapeutic and/or chemoprevention potentials.

Keywords: Salvia triloba, Salvia hormium, Salvia dominica, Salvia syriaca, Antiangiogenesis, MCF 7, Jordan

\section{Background}

Angiogenesis is the formation of new blood vessels. Cancer is angiogenesis dependent; any significant increment in tumour size must be in synchrony with increment in the blood supply. The new blood vessels supply the tumour cells with extra amount of oxygen and nutrients, and most importantly they facilitate cancer cell metastasis to other localities [1]. All solid tumours are dependent on the angiogenesis for tumour growth and metastasise [2]. Breast cancer is the most common cancer in women counting for approximately $27 \%$ of all new cancers [3]. It is characterized by a distinct metastatic pattern [4].

\footnotetext{
*Correspondence: M.zihlif@ju.edu.jo; aminmalikshah@gmail.com

'Department of Pharmacology, Faculty of Medicine, The University of Jordan, Amman 11942, Jordan

${ }^{3}$ Department of Pharmacology, School of Pharmaceutical Sciences, Universiti Sains Malaysia, Minden 11800, Penang, Malaysia

Full list of author information is available at the end of the article
}

Cancer cells within the tumour use the newly formed blood vessels as a port to metastasize to other localities [5]. Although less than $0.05 \%$ of circulating tumour cells has a potential to become stable metastases [6], the vast majority of breast cancer-related deaths result from metastatic tumours [7]. Angiogenesis, one of cancer hallmarks is involved in the progression and metastasis of breast cancer [8]. The process is tightly controlled through a balance of positive and negative regulatory factors and is triggered by pro-angiogenic growth factors [9]. Vascular endothelial growth factor (VEGF) is a major mediator of angiogenesis in cancer [10]. VEGF expression is induced under hypoxic conditions; a multistage process, in which the alpha subunit of hypoxia inducible factor-1 (HIF-1 $\alpha$ ) plays an important role [10]. Under normoxic condition, HIF- $1 \alpha$ rapidly decreases since it is bound to the tumour suppressor Von Hippel-Lindau (VHL) protein,

\section{Biomed Central}

(c) 2013 Zihlif et al.; licensee BioMed Central Ltd. This is an open access article distributed under the terms of the Creative Commons Attribution License (http://creativecommons.org/licenses/by/2.0), which permits unrestricted use, distribution, and reproduction in any medium, provided the original work is properly cited. 
which in turn results in HIF- $1 \alpha$ ubiquitynation and becomes a target for the proteosome. However, the low blood supplies toward the tumour mass drives the tumour tissue into hypoxia, which may induce transcriptional activation of VEGF expression through HIF- $1 \alpha$ stabilization [11]. Since angiogenesis plays a prominent role in tumour growth and metastasis, inhibition of angiogenesis is considered as an important strategy for cancer therapy [12]. Furthermore, inhibiting angiogenesis before it starts, which known as angioprevention, has the potential to block the expansion of hyperplastic foci and subsequent tumour development at the premalignant stage [13]. Angioprevention compounds work through diverse pathways, amongst those is the interference with expression of the VEGF and HIF-1 $\alpha$, which stand out among the diverse factors that drive angiogenesis [13].

The genus Salvia is the largest and the most important genus of the family Lamiaceae. This genus has about 900 species, widespread throughout the world, and includes several ornamental, culinary and medicinal species [14]. Nineteen species of Salvia are reported to occur in the flora of Jordan [15]. Published data indicated that many Salvia species exert diverse biological activities, and have been used in many parts of the world as part of the local traditional medicines to treat various conditions. Examples of pharmacological properties are antioxidant [16], antimicrobial [17], anti-inflammatory, analgesic [18], antipyretic, hemostatic [19], hypoglycemic [20] and anti-tumour [21] activities. $S$. miltiorrhiza Bunge, commonly used in traditional Chinese herbal medicine to treat cardiovascular and hepatic disorders, has been shown recently to have significant antitumour and anti-angiogenesis properties [22]. Interestingly, the same plant, $S$. miltiorrhiza, has demonstrated some proantiangiogenic activity. Another recent publication has also reported antiangiogenic activity for S. officinalis [23].

Encouraged from the promising results of S. officinalis, the current study was designed to evaluate the antiangiogenic activity of four Salvia species grown in Jordan. Ethanolic crude extracts of the leaves of S. dominica, S. syriaca, S. triloba and $S$. hormium were prepared and their direct antiangiogenic properties were investigated using rat aortic ring assay. Plant extracts that exhibited direct antiangiogenic activities, were further explored for their direct activity in human umbilical endothelial cells (HUVEC) cytotoxicity assay, migration assay and chicken embryo chorioallantoic membrane (CAM) assay. Moreover, to test the extracts' indirect antiangiogenic activity, the effect on the expression of the VEGF protein and expression of both, VEGF and HIF-1 $\alpha$ mRNA was examined using MCF 7 breast cancer cell line. All extracts were phytochemically screened using thin layer chromatography (TLC) and the presence of detected classes of secondary metabolites was reported. The effects of the extracts on normal cells were tested using periodontal fibroblast cell line (PLF).

\section{Methods}

\section{Plant samples collection and extraction}

Plant samples were collected during early flowering period (spring/summer 2009) from different areas in Jordan and have been identified by Prof. Dr. Barakat Abu Iremaileh (Faculty of Agriculture, The University of Jordan). Voucher specimens were deposited at the Department of Pharmaceutical Sciences, Faculty of Pharmacy, The University of Jordan. Plant samples were cleaned from extraneous material and dried at room temperature. Each $2.5 \mathrm{~g}$ of coarsely powdered plant material was extracted by refluxing with $25 \mathrm{~mL}$ $70 \%$ ethanol for $30 \mathrm{~min}$ and kept overnight at room temperature before filtration. After filtration, ethanol was evaporated until dryness and the crude extracts were weighed. The crude extracts were dissolved in dimethyl sulphoxide (DMSO) to a final stock concentration of $10 \mathrm{mg} / \mathrm{mL}$. All extracts were kept at $4^{\circ} \mathrm{C}$ until the time of experiment.

\section{Cell lines and cell culture}

The human breast adenocarcinoma (MCF 7) was purchased from the European Collection of Animal Cell Culture (ECACC). Fibroblast cell line provided kindly from the Faculty of Dentistry, Jordan University of Science and Technology. Human umbilical vein endothelial cell line (HUVEC) was purchased from American Type Cell Culture Collection (ATCC). The MCF 7 and fibroblast cell lines were cultured in DMEM/F12 and DMEM medium (Gibco, Invitrogen, USA), respectively. Media were supplemented with $10 \%$ fetal bovine serum (FBS) (Gibco, Invitrogen, USA), $1 \%$ of $2 \mathrm{mM}$ L-glutamine, $50 \mathrm{IU} / \mathrm{mL}$ penicillin and $50 \mu \mathrm{g} / \mathrm{mL}$ streptomycin (Lonza, Belgium). HUVECs were cultured in F12K medium (Gibco, Invitrogen, USA) supplemented with $0.1 \mathrm{~g} / \mathrm{mL}$ Heparin (Sigma, USA) and 1\% EGFR (Sigma, USA) 10\% FBS, 1\% of $2 \mathrm{mM} \mathrm{L}$-glutamine, $50 \mathrm{IU} / \mathrm{mL}$ penicillin and $50 \mu \mathrm{g} / \mathrm{mL}$ streptomycin. HUVECs from passages 2 through 4 were used through this study. All cells were maintained at $37^{\circ} \mathrm{C}$, $5 \% \mathrm{CO}_{2}$ in a humidified incubator.

\section{Rat aortic ring assay}

The rat aortic ring assay experiment was conducted after the experimental procedures were revised and approved by the Animal Ethics Committee of The University of Jordan. The assay was performed according to the standard protocol of Brown et al. [24], with minor modifications. Twelve to fourteen weeks old Sprague Dawley male rats were obtained from the animal house facility of the Faculty of medicine, The University of Jordan (UJ). The animals were humanely sacrificed via cervical dislocation under anesthesia with diethyl ether. Thoracic aorta was excised, rinsed with serum free media, cleaned from the fibroadipose tissue and was cross sectioned into thin rings of $1 \mathrm{~mm}$ thickness. M199 basal medium (Gibco, Invitrogen, USA) was used for the lower layer 
after adding fibrinogen and aprotinin (Sigma, USA) at $3 \mathrm{mg} / \mathrm{mL}$ and $5 \mu \mathrm{g} / \mathrm{mL}$, respectively. A $300 \mu \mathrm{l}$ of M199 medium was loaded in each 48-well plate and one aortic ring was seeded in each well. To each well, $10 \mu \mathrm{l}$ of thrombin (Sigma, USA); prepared at $50 \mathrm{NIH} \mathrm{U/mL} \mathrm{in} 0.15 \mathrm{M}$ $\mathrm{NaCl}$ : bovine serum albumin (1\%); was added and then was allowed to solidify at $37^{\circ} \mathrm{C}$ in $5 \% \mathrm{CO}_{2}$ for $60-90 \mathrm{~min}$. The top layer medium was prepared by adding the following to M199 basal medium: 20\% of heat inactivated fetal bovine serum (HIFBS) (Gibco, Invitrogen, USA), 1\% Lglutamine (Lonza, Belgium), 0.1\% aminocaproic acid (Sigma, USA), 1\% amphotericin B (Lonza, Belgium) and $0.6 \%$ gentamicin (Lonza, Belgium). Plant extracts were added to the top layer medium at concentration of $100 \mu \mathrm{g} / \mathrm{mL}$. The tissue rings were incubated at $37^{\circ} \mathrm{C}, 5 \%$ $\mathrm{CO}_{2}$ in a humidified incubator. On day 4, the top layer medium was changed with fresh medium prepared as previously mentioned. The DMSO (1\% v/v) and Suramin $(100 \mu \mathrm{g} / \mathrm{mL})$ were used as negative and positive controls respectively. The results examined microscopically at appropriate magnification and the magnitude of blood vessel outgrowth was quantified using Leica Quin software package [25], according to the technique developed by Nicosia et al. [26]. The results are presented as mean percent inhibition to the negative control $\pm S D,(n=3)$.

\section{In vitro cytotoxicity assay}

Plant extracts were tested for cytotoxicity against fibroblast cell line. Cells were seeded at density of 10,000 cells/ well in 96-well plates. Afterwards, the cells were treated with two concentrations; 50 and $100 \mu \mathrm{g} / \mathrm{mL}$ in quadricate. Control wells contained DMSO at same concentrations. After $72 \mathrm{~h}$ incubation, cell viability was determined by MTT assay according to cell proliferation assay kit (Promega, USA). Absorbance (OD) was measured at $570 \mathrm{~nm}$ with background subtraction at $630 \mathrm{~nm}$.

\section{Antiproliferative activity}

HUVECs were seeded at a density of $10 \times 10^{3}$ cells/well in 96-well plates and allowed to attach overnight. Plant extracts that showed antiangiogenic activity with aortic ring assay were screened on HUVECs for their $\mathrm{IC}_{50}$. Cells were treated with different concentrations (1.5$100 \mu \mathrm{g} / \mathrm{mL}$ ) in quadricate. After $72 \mathrm{~h}$ treatment, MTT assay was performed according to cell proliferation assay kit (Promega, USA). Absorbance (OD) was measured at $570 \mathrm{~nm}$ with background subtraction at $630 \mathrm{~nm}$. The calculation of $\mathrm{IC}_{50}$ was performed using a sigmoidal plotting function provided in the GraphPad Prism software. DMSO was used as a negative control.

\section{Wound healing migration assay}

The migration assay was carried out as described previously [27]. Briefly, HUVECs were seeded at $5 \times 10^{5} /$ well in 6-well plates and allowed to form a confluent monolayer. The layer of cells was then scraped with a 20-200 $\mu \mathrm{l}$ micropipette tip to create a wound of $\sim 1 \mathrm{~mm}$ width. Cells were then washed twice with PBS and replaced with medium containing 100 AND $150 \mu \mathrm{g} / \mathrm{mL}$ of the plant extracts. The wounds were photographed at 0,12 and $18 \mathrm{~h}$, and the number of migrated cells was counted. Ten readings per well were taken. The results are presented as mean percentage of migration inhibition to the control $\pm \mathrm{SD},(\mathrm{n}=3)$.

\section{In vivo CAM assay}

Antiangiogenic effect of the plant extracts was investigated in vivo using CAM assay as mentioned previously [28]. Five day-old fertilized eggs were obtained from local hatchery. $5 \mathrm{~mL}$ of albumin was aspirated and the eggs were incubated horizontally to allow the CAM to detach from the shell. Chosen extracts were prepared in $1.2 \%$ agarose discs at concentration of $100 \mu \mathrm{g} /$ disc. Discs containing the vehicle only (DMSO) were used as negative control. A small window opening was made in the shell, and the discs were directly applied onto the CAM. The square opening was covered with sterilized surgical tape and the embryos were incubated for $48 \mathrm{~h}$ at $37^{\circ} \mathrm{C}$. The CAMs were photographed under a dissecting microscope and blood vessels in each CAM were counted. The results are presented as a mean percentage of inhibition to the control $\pm S D,(n=3)$.

\section{Expression of VEGF and HIF-1a MCF 7 cells treatment}

MCF 7 cells were seeded at a concentration of $3 \times 10^{6}$ cells in T75 Flask on the day before treatment. Then, the medium was replaced with a new medium, containing three concentrations of plant extract 100, 200 and $300 \mu \mathrm{g} / \mathrm{mL}$. The cells were incubated at $37^{\circ} \mathrm{C}, 5 \% \mathrm{CO}_{2}$ for $16 \mathrm{~h}$, under two conditions; hypoxic $\left(0.1 \% \mathrm{O}_{2}\right)$ and normoxic conditions $\left(20 \% \mathrm{O}_{2}\right)$. However, before cells were exposed to the hypoxic condition, they were treated under normoxic condition for $1 \mathrm{~h}$ then maintained under hypoxic conditions for $16 \mathrm{~h}$. Hypoxic condition was performed by incubating the cells in GasPak Pouch (Becton Dickinson, Sparks, Md., USA). DMSO with the same concentrations as the extracts were then used as negative controls. Then, cells were harvested for RNA extraction.

\section{RNA extraction and CDNA synthesis}

Total RNA was extracted using Trizol, LS (Invitrogen, USA). The RNA quality was assessed by spectrophotometric method $\left(\mathrm{A}_{260} / \mathrm{A}_{280}\right)$. RNA samples were stored at $-80^{\circ} \mathrm{C}$ until used. Complementary DNA (cDNA) was synthesized from $1.0 \mu \mathrm{g}$ total RNA using RT-PCR Kit (Promega, USA) in a final volume of $20 \mu \mathrm{l}$ using random primers according to the manufacturer's instructions. 


\section{Quantitative real-time $P C R$ (Q-PCR)}

Q-PCR was carried out in IQ4 real time PCR (BioRad, USA). The reaction mixture consisted of $1 \mathrm{X}$ GoTaq qPCR Master Mix (12.5 $\mu$ l) (Promega, USA), $2.5 \mu \mathrm{l}$ primers and $1.0 \mu \mathrm{l}$ of cDNA in a total volume of $25 \mu \mathrm{l}$. VEGF and HIF-1 $\alpha$ QuantiTect Sybr green primers were purchased from Qiagen, Germany. GAPDH was used as internal reference control. GAPDH primers (Invitrogen, USA) sequences used in this study were as previously mentioned [29]. The PCR condition for GAPDH, VEGF and HIF- $1 \alpha$ comprised of first incubation at $95^{\circ} \mathrm{C}$ for $15 \mathrm{~min}, 40$ cycles of denaturation at $95^{\circ} \mathrm{C}$ for $15 \mathrm{sec}$, annealing at $55^{\circ} \mathrm{C}$ for $30 \mathrm{sec}$, extension at $72^{\circ} \mathrm{C}$ for $30 \mathrm{sec}$. Fluorescence was recorded at the end of extension. A negative control without cDNA template was run simultaneously with every assay. To generate a standard curve, template cDNA from untreated-control MCF 7 cells was used. Quantification of gene expression was calculated by the standard curve and cycle threshold of each sample. The results of genes expression were normalized to reference gene expression and the fold exchange was determined in comparing with untreated cell control. Two replicates of this experiment were carried out, in which every gene had a duplicated reading. A melt curve analysis was done after QPCR to ensure the specificity of PCR product.

\section{Determination of VEGF protein level}

MCF 7 cells were seeded in a 96-well plate at a density of $1 \times 10^{5} \mathrm{cells} /$ well and incubated overnight. Cells were cultured in a serum free medium for $2 \mathrm{~h}$ and then replaced with $10 \%$ FBS medium in presence of various doses of plant extracts at $100,200,300 \mu \mathrm{g} / \mathrm{mL}$ concentrations for $48 \mathrm{~h}$ under normoxic and hypoxic conditions. control wells were treated with DMSO Hypoxic condition were performed by incubating the cells in GasPak Pouch (Becton Dickinson, Sparks, Md., USA). Each concentration was prepared in triplicates. The negative control used was DMSO, with the same concentrations of the extracts. Media from each well was collected and stored at $-20^{\circ} \mathrm{C}$ until tested. VEGF concentrations in the conditioned media were quantified by Quantikine Human VEGF ELISA kit (R\&D Systems, Minneapolis, USA) according to the manufacturer's protocol. MTT assay was used for correcting the amount of VEGF produced to the number of viable cells.

\section{Statistical analysis}

Results were presented as means $\pm \mathrm{SD}$. The differences between groups were compared by the one way ANOVA followed by Tukey Post-hoc test and considered significant at $P<0.05$. The statistical analysis was carried out by using SSPS edition 16.0.

\section{Results}

Rat aortic ring assay

In order to evaluate the antiangiogenic properties of the plant extracts, we performed the rat aortic ring assay at two concentrations: 50 and $100 \mu \mathrm{g} / \mathrm{mL}$ (Figure 1). All of the 4. Salvia ethanolic extracts exhibited high inhibitory activity when tested at $100 \mu \mathrm{g} / \mathrm{mL}$; they resulted in more than $70 \%$ of the mean percent inhibition to the vehicle $(P<0.05)$ (Table 1). Interestingly, at $50 \mu \mathrm{g} / \mathrm{mL}$, the four extracts demonstrated different behavior. S. dominica and S. syriaca continued to show the highest inhibitory effects (Table 1 and Figure 1). While, S. hormium failed to keep any inhibitory activity at this concentration $(P>0.05)$ (Table 1 and Figure 1). S. triloba succeed in keeping its inhibitory activity and scored $77.67 \pm 5.97 \%$ vessel outgrowth inhibition $(P<0.05)$ (Table 1 and Figure 1$)$.

\section{In vitro cytotoxicity assay}

To assess the cytotoxicity effects of the four Salvia extracts on normal cells, we tested the effect of those extracts at $100 \mu \mathrm{g} / \mathrm{mL}$ on the proliferation of periodontal ligament fibroblasts cells (PLF) in culture. As indicated in Table 1, S. dominica and S. syriaca exhibited clear cytotoxic effects by reducing the cells viability to less than $25 \%(P<0.05)$. On the other hand, S. triloba and S. hormium showed no or negligible inhibitory effect on PLF cell proliferation $(P>0.05)$.

\section{Antiproliferative activity against HUVECs}

In order to confirm the direct antiangiogenic activity which is demonstrated in the rat aortic assay, the effects of the non-toxic extracts on PLF cells on two of HUVEC functions (proliferation and migration) were evaluated. In HUVEC proliferation assay, S. triloba and S. hormium exhibited $\mathrm{IC}_{50}$ of $90.0 \pm 0.4$ and $121.0 \pm 3.5 \mu \mathrm{g} / \mathrm{mL}$, respectively. The antiproliferative effect of these plant extracts on HUVECs did not result from a cytotoxic effect, because 90 , $111 \%$ of the endothelial cells were alive at $50 \mu \mathrm{g} / \mathrm{mL}$ concentration after $72 \mathrm{~h}$ treatment, respectively.

\section{Wound healing migration assay}

The scratch wound healing assay was performed to evaluate the effect of $S$. triloba and S. hormium extracts on HUVEC migration. Wound repair by endothelial cells was observed in untreated control wells. In contrast, inhibition of migration was clearly observed in wells with S. triloba at $100 \mu \mathrm{g} / \mathrm{mL}$ and $150 \mu \mathrm{g} / \mathrm{mL}$ concentration after $18 \mathrm{~h}$ incubation with $55.6 \pm 5.2 \%(P=0.000)$ and $80.6 \pm 3.9 \%(P=0.000)$ inhibition, respectively (Figure 2$)$. While $S$. hormium at $100 \mu \mathrm{g} / \mathrm{mL}$ showed insignificant inhibition at $100 \mu \mathrm{g} / \mathrm{mL}$ with $6.48 \pm 3.9 \%(P>0.05)$, and a modest inhibition at $150 \mu \mathrm{g} / \mathrm{mL}$ concentration with $23.2 \pm 2.5 \%$ compared to controls $(P=0.001)$ (Figure 2 ). 

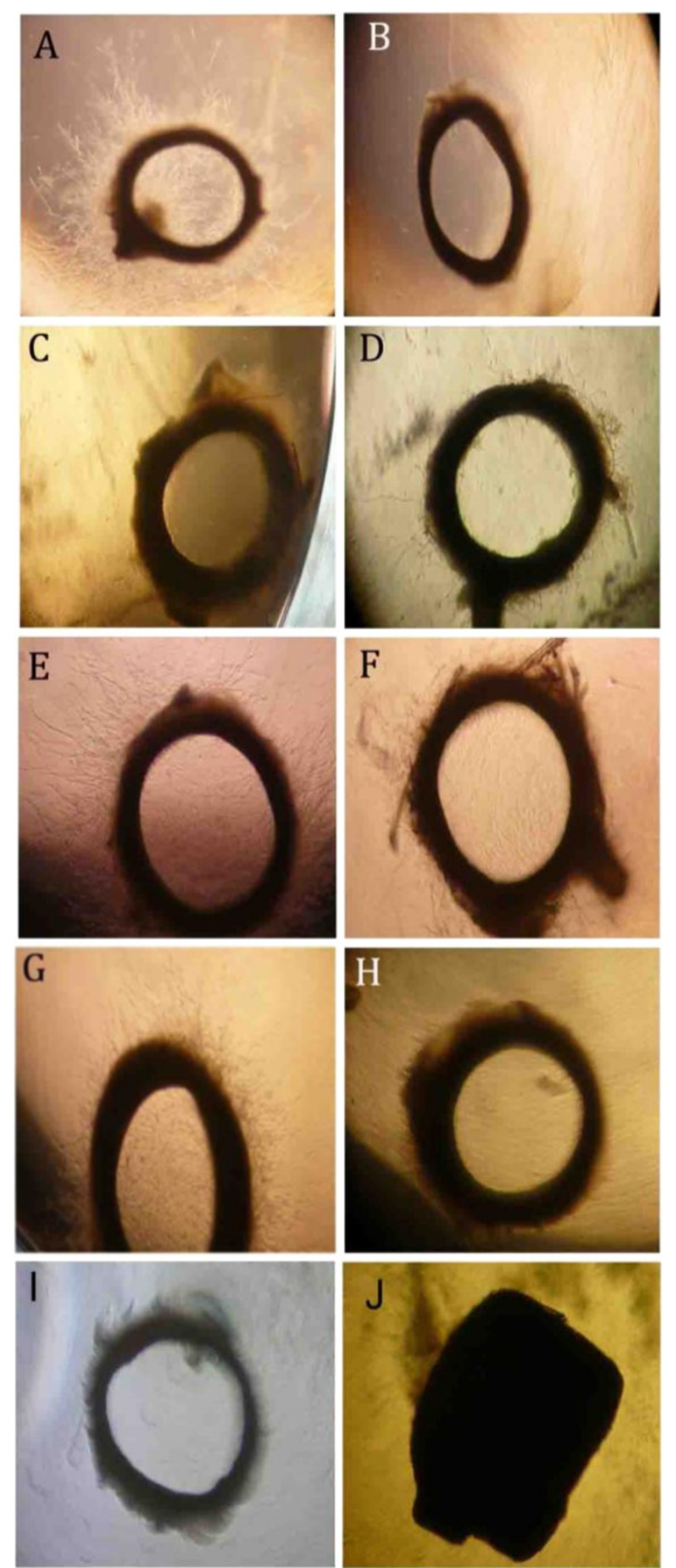

Figure 1 Effect of selected plant extracts on rat aortic vessel outgrowth. (A) negative control (B) positive control (Suramine) (C, D) 50 and $100 \mu \mathrm{g} / \mathrm{mL}$ of $S$. dominica (E, F) 50 and $100 \mu \mathrm{g} / \mathrm{mL}$ of $S$. hormium, $(\mathbf{G}, \mathbf{H}) 50$ and $100 \mu \mathrm{g} / \mathrm{mL}$ of S. triloba and 50 and $100 \mu \mathrm{g} / \mathrm{mL}$ of S. syriaca $(\mathbf{I}, \mathbf{J})$.

\section{In vivo CAM assay}

In vivo antiangiogenic effect of $S$. triloba and S. hormium were also tested using CAM assay as an in vivo model at a dose of $100 \mu \mathrm{g} / \mathrm{mL}$. As shown in Figure 3, a clear
Table 1 Column 1: list of the plant extracts

\begin{tabular}{|c|c|c|c|}
\hline $\begin{array}{l}\text { Plant } \\
\text { name }\end{array}$ & $\begin{array}{l}\text { Aortic assay } \\
\% \text { of inhibition } \\
(100 \mu \mathrm{g} / \mathrm{mL})\end{array}$ & $\begin{array}{l}\text { Aortic assay } \\
\% \text { of inhibition } \\
(50 \mu \mathrm{g} / \mathrm{mL})\end{array}$ & $\begin{array}{l}\text { PFL cells } \\
\% \text { viability } \\
(100 \mu \mathrm{g} / \mathrm{mL})\end{array}$ \\
\hline S. syriaca & $\begin{array}{l}100.0 \pm 0.0 \\
(P=0.000)\end{array}$ & $\begin{array}{l}100.0 \pm 0.0 \\
(P=0.000)\end{array}$ & $\begin{array}{l}20.2 \pm 1.6 \\
(P=0.000)\end{array}$ \\
\hline S. dominica & $\begin{array}{l}100.0 \pm 0.0 \\
(P=0.000)\end{array}$ & $\begin{array}{l}84.1 \pm 5.4 \\
(P=0.000)\end{array}$ & $\begin{array}{l}13.8 \pm 7.9 \\
(P=0.000)\end{array}$ \\
\hline S. hormium & $\begin{array}{l}77.1 \pm 6.8 \\
(P=0.000)\end{array}$ & $\begin{array}{l}3.1 \pm 1.2 \\
(P=0.995)\end{array}$ & $\begin{array}{l}111.7 \pm 2.0 \\
(P=0.000)\end{array}$ \\
\hline S. triloba & $\begin{array}{l}97.1 \pm 0.8 \\
(P=0.000)\end{array}$ & $\begin{array}{l}77.76 \pm 5.96 \\
(P=0.000)\end{array}$ & $\begin{array}{l}90.0 \pm 3.7 \\
(P=0.902)\end{array}$ \\
\hline
\end{tabular}

Column 2 and 3: show the rat aorta ring assay results as a mean percent inhibition to the vehicle (DMSO) \pm S.D at two concentrations of 50 and $100 \mu \mathrm{g} /$ $\mathrm{mL}$. Column 4: show the cytotoxic effect of the plant extracts on the proliferation of PFL cells at $100 \mu \mathrm{g} / \mathrm{mL}$.

inhibitory activity for the $S$. triloba extract with $49.1 \pm 4.1 \%$ $(P=0.001)$ inhibition was observed, while $S$. hormium extract showed insignificant inhibition $20 \pm 5.3 \%(P>0.005)$.

\section{Q-PCR for VEGF and HIF-1a expression after S. triloba treatment}

Two steps RT-QPCR were used to evaluate VEGF and HIF- $1 \alpha$ mRNA expression in MCF 7 cells after the treatment with $S$. triloba extract. As shown in Figure 4, the $S$. triloba extract showed a significant down-regulatory effect on the expression of HIF- $1 \alpha$ mRNA at the 3 concentrations $(100 \mu \mathrm{g} / \mathrm{mL}, 200 \mu \mathrm{g} / \mathrm{mL}$ and $300 \mu \mathrm{g} / \mathrm{mL})$ under normoxic and at 200 and $300 \mu \mathrm{g} / \mathrm{mL}$ under hypoxic conditions $(P<0.05)$. This inhibitory activity reached the maximum at the $300 \mu \mathrm{g} / \mathrm{mL}(P=0.00)$, where the HIF-1 $\alpha$ mRNA expressions were down-regulated approximately 4 and 2.5 fold at the normoxic and hypoxic conditions, respectively. On the VEGF side, the inhibition of the expression was only observed at the $300 \mu \mathrm{g} / \mathrm{mL}$ under both the normoxic and the hypoxic conditions $(P<0.05)$.

\section{Decreased levels of VEGF protein expression in MCF 7 cells after S. triloba treatment}

As shown in Figure 5, the S. triloba extract was very effective in reducing the protein level under both, hypoxic and normoxic conditions in a dose dependent manner. Interestingly, the $S$. triloba extract decreased the VEGF protein level using 1, 2, 3 times $\mathrm{IC}_{50}$ concentration (90, $180,270 \mu \mathrm{g} / \mathrm{mL})$ by $15.4 \%(P=0.266), 89.3 \%(P=0.000)$ and $97.4 \%(P=0.000)$ under normoxic conditions and by 31.9\% $(P=0.000) 84.5 \%(P=0.000)$ and $90.2 \%(P=0.000)$ of inhibition under hypoxic conditions.

\section{Thin layer chromatography (TLC) of the extracts}

All four plants showed the presence of terpenoids and flavonoids. Using preparative TLC techniques and in 

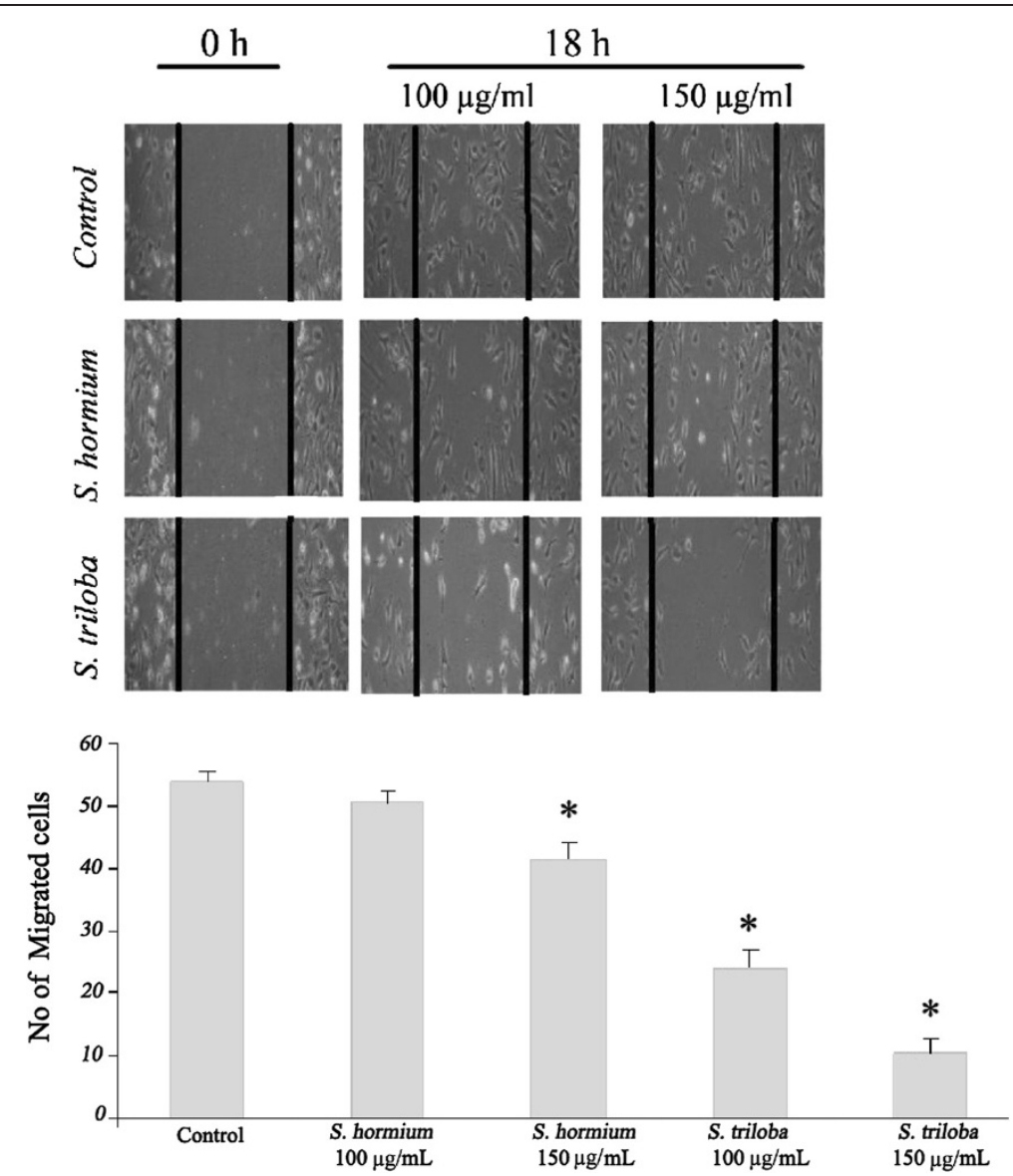

Figure 2 Effects of S. triloba and S. hormium on HUVEC migration. A scratch is created and then cells were treated with or 100 and $150 \mathrm{\mu g} / \mathrm{mL}$ of plant extract for $18 \mathrm{~h}$. The graph represents the number of migrated cells after 18 hours treatment for the two extracts at two concentrations. ${ }^{*} P<0.05$.

comparison with the reference substances, the main volatile oils components identified were alpha terpineol and 1,8- cineol and the major flavonoid traced was quercetin.

\section{Discussion}

Angiogenesis is an essential step in solid tumour development, invasion, and metastasis. The antiangiogenesis strategy has been postulated for prevention and treatment of breast cancers [30]. There are two accepted ways to modulate angiogenesis, namely direct and indirect pathways. The direct way depends on modulating the vascular endothelial cells ability to proliferate, migrate and respond to angiogenic proteins such as VEGF. The indirect way is based on the ability to alter the expression as well as to change the activity of angiogenic proteins that activate angiogenesis. This also includes regulating the expression of the receptors on endothelial cells [31]. In the present study, the angiogenic activity of the crude ethanol extracts of four Salvia species grown in Jordan (S. dominica, S. syriaca, S. triloba and S. hormium) has been investigated.
Starting from the direct angiogenic findings, all four extracts have significantly inhibited the formation of new blood vessels in the rat aortic assay at $100 \mu \mathrm{g} / \mathrm{mL}$. Interestingly, the reduction in the concentration to $50 \mu \mathrm{g} / \mathrm{mL}$ for the four extracts revealed different behavior. S. dominica, S. syriaca, S. triloba extracts continued to show a significant inhibitory activity $(P<0.05)$, while $S$. hormium failed to show any inhibitory activity $(P>0.05)$. To test whether this activity is a selective antiangiogenic or a result of a direct cytotoxic activity, the anti-PLF proliferative test at $100 \mu \mathrm{g} / \mathrm{mL}$ was performed. The results indicated that $S$. dominica and S. syriaca have significant cytotoxic effects $(P=0.000)$. These observations clearly point out that the strong inhibitory activity of $S$. dominica and $S$. syriaca belongs to their strong cytotoxic effects rather than their selective antiangiogenic actions. Based on these findings, these two extracts were excluded from further experiments and emphasis was given on the non-toxic extracts, S. triloba and S. hormium.

The direct antiangiogenic activity of the two extracts of S. triloba and S. hormium were tested further on two 

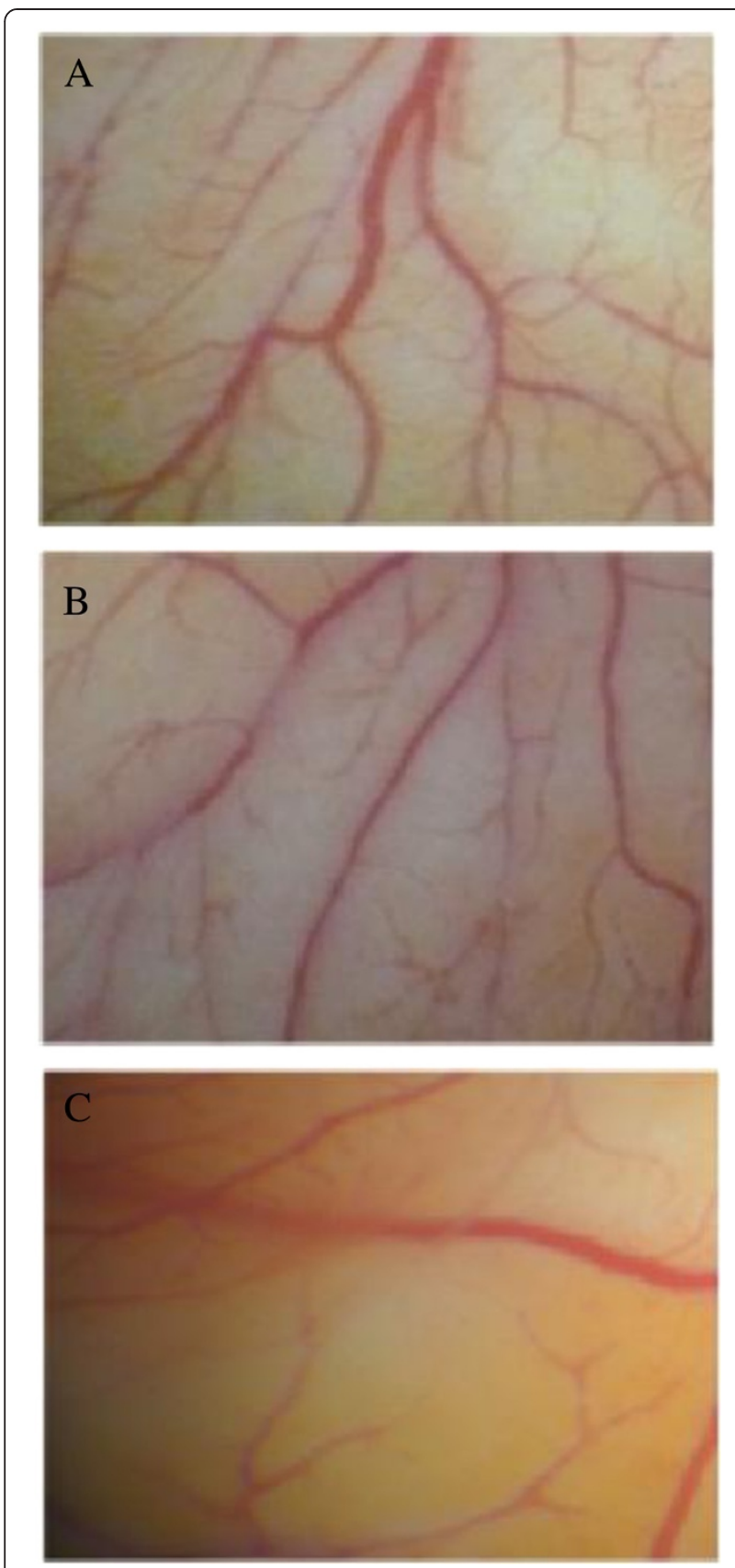

Figure 3 Effect of S. triloba and S. hormium on neovascularization in CAM assay. The embryos were treated for $24 \mathrm{~h}$ with (A) $1 \%$ DMSO as negative control, (B) S. hormium $100 \mu \mathrm{g} / \mathrm{mL}$ and (C) S. triloba $100 \mu \mathrm{g} / \mathrm{mL}$

HUVEC functions, namely: endothelial cell proliferation and endothelial cell migration. These two assays represent two major steps in angiogenesis process. The antiHUVEC proliferation results showed that the $\mathrm{IC}_{50}$ value of S. triloba and S. hormium are $90 \pm 0.36$ and $121 \pm$ $3.47 \mu \mathrm{g} / \mathrm{mL}$, respectively. The obtained $\mathrm{IC}_{50}$ indicated that the two extracts do possess a direct anti-proliferation activity against the HUVECs. The values also point out that the two extracts do not have a direct cytotoxic activity against HUVECs as the two $\mathrm{IC}_{50}$ values are far from the $20 \mu \mathrm{g} / \mathrm{mL}$; the $\mathrm{IC}_{50}$ that has been chosen as an indication of a direct toxic activity of the plant extracts [32]. Interestingly, the results of migration assay of both extracts illustrated that $S$. triloba inhibits significantly HUVEC migration in concentration-dependent manner, while $S$. hormium showed significant inhibitory activity only at the highest concentrations $(P=0.000)$. The final step in the direct angiogenesis investigation was to test for antiangiogenic activity in vivo. The vascularization in chick embryo was chosen as an in vivo model. Again, the highly significant ability of inhibiting the formation of new blood vessels by $S$. triloba were obvious $(P=0.001)$, the finding that enforced the in vitro observation and voted for the high potential of S. triloba as inhibitor of many crucial steps of the angiogenesis process.

As to the indirect angiogenic activity, the investigation was limited to S. triloba, where we assessed the effect of ethanolic extracts of $S$. triloba on VEGF and HIF- $1 \alpha$ mRNA and VEGF protein expression under normoxic and hypoxic conditions. The protein expression measurement was limited on the VEGF because it is the principle mediator of tumour angiogenesis [33]. The mRNA and protein expression measurements were conducted at two conditions, the normoxic and hypoxic conditions. The hypoxic environment was adapted to resemble the in vivo tumour conditions, in which the VEGF expression is known to be elevated [34,35]. Interestingly, S. triloba demonstrated a significant inhibitory activity on expression of the VEGF and HIF- $1 \alpha$ mRNA, and also on the protein expression of VEGF under normoxic and hypoxic conditions $(P<0.05)$. Interestingly, in comparison with normoxic condition, the hypoxic condition up-regulate the VEGF protein expression 1.5 times, and $S$. triloba illustrated a high potency in reversing this over-expression. Combining these indirect angiogenic findings with the fact that VEGF is one of the major HIF-1 targeted genes, specifically in recruiting the endothelial cells into hypoxic and vascular areas does point that the alteration in expression the of VEGF mRNA and protein by $S$. triloba may resulted from modulating the HIF-1 expression [10].

Taken the direct and indirect antiangiogenic investigations on crude ethanol extracts of four Salvia species, $S$. triloba can be nominated as a potent antiangiogenic plant that may have chemotherapeutic and/or chemoprevention potentials. Chemoprevention potentials are summarized by its direct antiangiogenic ability via the inhibition of the endothelial cell proliferation and its indirect antiangiogenic ability through inhibiting the VEGF expression. Since VEGF ligand may affect tumour vasculature in early tumour development through the recruitment of bonemarrow-derived progenitor cells that form the building blocks of a new vascular network [35], it is tempting to 


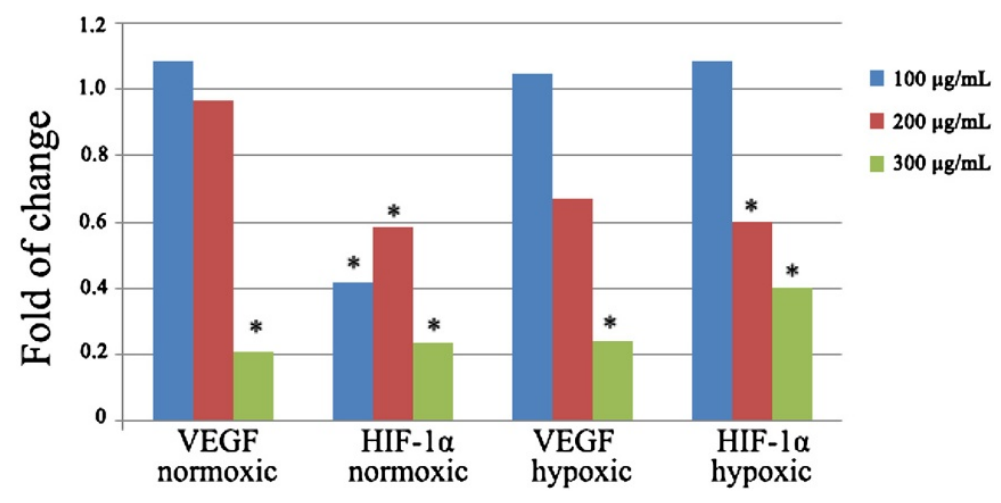

Figure 4 The effect of S. triloba on VEGF and HIF-a mRNA expression after $16 \mathrm{~h}$ treatment at normoxic and hypoxic conditions.

speculate that the antiangiogenic mechanisms described here might contribute to its angiopreventive effect. VEGF also work throughout tumour development, in which it helps existing vasculature survive, hence permitting tumours to sustain their requirements over their entire life cycle. Furthermore, the chemotherapeutic potential of S. triloba was noticed through significant inhibitory activity of this plant against HIF- $1 \alpha$ mRNA expression, which is a master transcription factor related to cell proliferation/ survival and resistance to chemotherapy and radiation [34]. Importantly, HIF- $1 \alpha$ antisense therapy demonstrated a synergistic anti-tumour effect with immunotherapy [36]. Moreover, the angioprevention activity can also be speculated building on the significant inhibitory activity of $S$. triloba against HIF- $1 \alpha$ mRNA expression. HIF- $1 \alpha$ is one of the most important transcription factors that operate to sense environmental clues that drives angiogenesis [13]. Importantly, Hao et al. (2011) showed that RNAi targeting HIF- $1 \alpha$ is effectively inhibiting the progression of oral squamous cell carcinoma and concluded that it may be used as a potent and specific therapy for oral cancer, especially in inhibiting and preventing cancer cell angiogenesis and survival [37].
On the other hand, the chemoprevention values perhaps will be more convincing by knowing that this plant is very popular in the Middle East, especially in the Arabic countries such as Jordan and Palestine [38,39], where people consume $S$. triloba on daily basis, either by drinking it alone or using it as a flavoring agent to black tea. Further studies are needed to include $S$. triloba to the list of dietary phytochemicals for which chemopreventive activities by interfering with multiple signaling pathways aberrant in cancer have been demonstrated [40-43].

\section{Conclusion}

Out of the four crude ethanol extracts of four Salvia species grown in Jordan (S. dominica, S. syriaca, S. triloba and S. hormium). S. triloba has shown a potent direct and indirect antiangiogenic activity that may have chemotherapeutic and/or chemoprevention potentials. The direct antiangiogenic activity were proven using the rat aortic assay, The anti-HUVEC proliferation, migration assay and CAM assay. The indirect antiangiogenic activity were proven through assessing the effect on VEGF and HIF- $1 \alpha$ mRNA and VEGF protein expression under normoxic and hypoxic conditions.

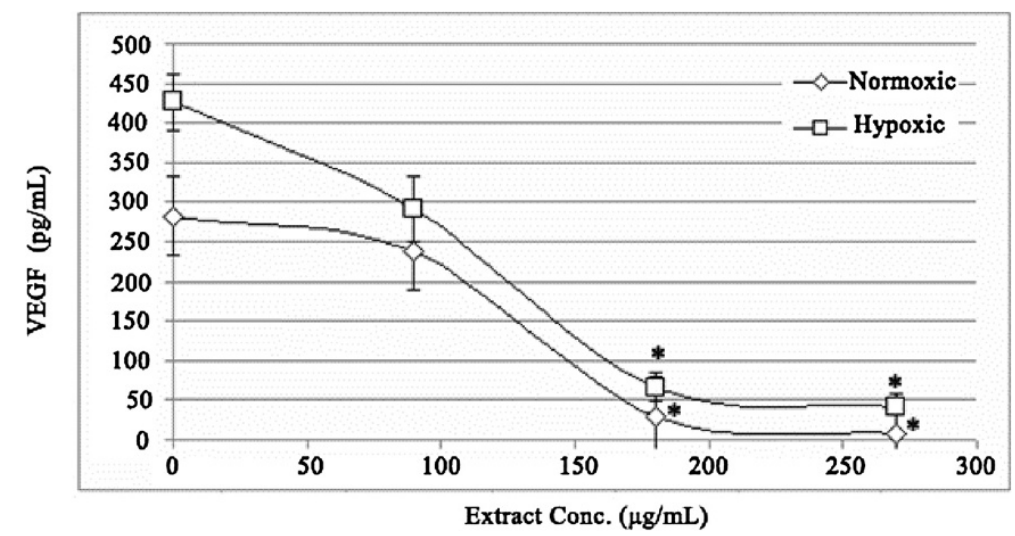

Figure 5 The effect of S. triloba on VEGF protein expression after $48 \mathrm{~h}$ treatment at normoxic and hypoxic conditions. 


\section{Competing interests}

The authors declare that they have no competing interests.

\section{Authors' contribution}

$M Z, F A, R A D$ and AMSAM contributed to the design of the study, the analysis of the data, and drafted the manuscript. HS, MMS, ZDN and RN executed the experiments. All the authors have read and approved the final manuscript.

\section{Acknowledgment}

This research was supported by a grant to M. Zihlif from Academic Deanship of Research at The University of Jordan.

\section{Author details}

'Department of Pharmacology, Faculty of Medicine, The University of Jordan, Amman 11942, Jordan. Department of Pharmaceutical Sciences, Faculty of Pharmacy, The University of Jordan, Amman, Jordan. ${ }^{3}$ Department of Pharmacology, School of Pharmaceutical Sciences, Universiti Sains Malaysia, Minden 11800, Penang, Malaysia. ${ }^{4}$ University of Queensland, School of Pharmacy, 20 Cornwall Street, Woolloongabba, QLD 4102, Australia. ${ }^{5}$ Department of Physiology and Biochemistry, Faculty of Medicine, The University of Jordan, Amman 11942, Jordan.

Received: 8 January 2013 Accepted: 29 November 2013

Published: 13 December 2013

\section{References}

1. Folkman J: Role of angiogenesis in tumor growth and metastasis. Semin Oncol 2002, 29(6, Supplement 16):15-18.

2. Folkman J: What is the evidence that tumors are angiogenesis dependent? J Natl Cancer Inst 1990, 82(1):4-7.

3. Jemal A, Siegel R, Ward E, Hao Y, Xu J, Thun MJ: Cancer Statistics, 2009. CA Cancer J Clin 2009, 59(4):225-249.

4. Steeg PS: Tumor metastasis: mechanistic insights and clinical challenges. Nat Med 2006, 12(8):895-904

5. Weidner N, Semple JP, Welch WR, Folkman J: Tumor angiogenesis and metastasis-correlation in invasive breast carcinoma. N Engl J Med 1991, 324(1):1-8.

6. Geho DH, Bandle RW, Clair T, Liotta LA: Physiological mechanisms of tumor-cell invasion and migration. Physiology 2005, 20(3):194-200.

7. Weigelt B, Peterse JL, van't Veer LJ: Breast cancer metastasis: markers and models. Nat Rev Cancer 2005, 5(8):591-602.

8. Quesada AR, Muñoz Chápuli R, Medina MA: Anti angiogenic drugs: from bench to clinical trials. Med Res Rev 2006, 26(4):483-530.

9. Browder T, Folkman J, Pirie-Shepherd S: The hemostatic system as a regulator of angiogenesis. J Biol Chem 2000, 275(3):1521.

10. Pugh CW, Ratcliffe PJ: Regulation of angiogenesis by hypoxia: role of the HIF system. Nat Med 2003, 9(6):677-684.

11. Carmeliet $P$, Jain RK: Angiogenesis in cancer and other diseases. Nature 2000, 407(6801):249-257

12. Denekamp J: Angiogenesis, neovascular proliferation and vascular pathophysiology as targets for cancer therapy. Br J Radiol 1993, 66 (783): 181 .

13. Albini A, Noonan DM, Ferrari N: Molecular Pathways for Cancer Angioprevention. Clin Cancer Res 2007, 13(15):4320-4325.

14. Goren AC, Kilic T, Dirmenci T, Bilsel G: Chemotaxonomic evaluation of Turkish species of Salvia: fatty acid compositions of seed oils. Biochem Syst Ecol 2006, 34(2):160-164.

15. Al-Eisawi DM: List of Jordan vascular plants. Amman 1982, 152:79-182.

16. Lima CF, Valentao PCR, Andrade PB, Seabra RM, Fernandes-Ferreira M, Pereira-Wilson C: Water and methanolic extracts of Salvia officinalis protect HepG2 cells from t-BHP induced oxidative damage. Chem Biol Interact 2007 167(2):107-115.

17. González AG, Abad T, Jiménez IA, Ravelo AG, Luis Zahira Aguiar JG, San Andrés L, Plasencia M, Herrera JR, Moujir L: A first study of antibacterial activity of diterpenes isolated from some Salvia species (Lamiaceae). Biochem Syst Ecol 1989, 17(4):293-296.

18. Hosseinzadeh $H$, Haddadkhodaparast MH, Arash AR: Antinociceptive, antiinflammatory and acute toxicity effects of Salvia leriifolia Benth. Seed extract in mice and rats. Phytother Res 2003, 17(4):422-425.

19. Hernandez-Perez M, Rabanal RM, de la Torre MC, Rodriguez B: Analgesic, anti-inflammatory, antipyretic and haematological effects of aethiopinone, an o-naphthoquinone diterpenoid from Salvia aethiopis roots and two hemisynthetic derivatives. Planta Med 1995, 61(6):505-509.

20. Alarcon Aguilar F, Roman Ramos R, Flores Saenz J, Aguirre Garcia F: Investigation on the hypoglycaemic effects of extracts of four Mexican medicinal plants in normal and Alloxan diabetic mice. Phytother Res 2002, 16(4):383-386

21. Liu J, Shen HM, Ong CN: Salvia miltiorrhiza inhibits cell growth and induces apoptosis in human hepatoma HepG2 cells. Cancer Lett 2000, 153(1-2):85-93.

22. Wu MH, Tsai WJ, Don MJ, Chen YC, Chen IS, Kuo YC: Tanshinlactone A from Salvia miltiorrhiza modulates interleukin-2 and interferon-gamma gene expression. J Ethnopharmacol 2007, 113(2):210-217.

23. Keshavarz M, Mostafaie A, Mansouri K, Bidmeshkipour A, Motlagh HRM, Parvaneh S: In vitro and ex vivo antiangiogenic activity of salvia officinalis. Phytother Res 2010, 24(10):1526-1531.

24. Brown KJ, Maynes SF, Bezos A, Maguire DJ, Ford MD, Parish CR: A novel in vitro assay for human angiogenesis. Lab Invest 1996, 75(4):539-555.

25. Nassar ZD, Aisha AF, Ahamed MB, Ismail Z, Abu-Salah KM, Alrokayan SA, Abdul Majid AM: Antiangiogenic properties of Koetjapic acid, a natural triterpene isolated from Sandoricum koetjaoe Merr. Cancer Cell Int 2011, 11(1):12

26. Nicosia RF, Lin YJ, Hazelton D, Qian X: Endogenous regulation of angiogenesis in the rat aorta model Role of vascular endothelial growth factor. Am J Pathol 1997, 151(5):1379-1386.

27. Liang CC, Park AY, Guan JL: In vitro scratch assay: a convenient and inexpensive method for analysis of cell migration in vitro. Nat Protoc 2007, 2(2):329-333.

28. West DC, Burbridge MF: Three-dimensional in vitro anglogenesis in the rat aortic ring model. Methods Mol Biol 2009, 467:189-210.

29. Kaneda R, Toyota M, Yamashita Y, Koinuma K, Choi YL, Ota J, Kisanuki H, Ishikawa M, Takada S, Shimada K: High-throughput screening of genome fragments bound to differentially acetylated histones. Genes Cells 2004, 9 (12):1167-1174.

30. Sogno I, Venč R, Ferrari N, De Censi A, Imperatori A, Noonan DM, Tosetti F, Albini A: Angioprevention with fenretinide: targeting angiogenesis in prevention and therapeutic strategies. Crit Rev Oncol Hematol 2010, 75(1):2-14.

31. Kerbel R, Folkman J: Clinical translation of angiogenesis inhibitors. Nat Rev Cancer 2002, 2(10):727-739.

32. Boik J: Natural compounds in cancer therapy. LLC, Minnesota, USA: Oregon Medical Press; 2001

33. Hicklin DJ, Ellis LM: Role of the vascular endothelial growth factor pathway in tumor growth and angiogenesis. J Clin Oncol 2005, 23(5):1011.

34. Brown JM, Giaccia AJ: The unique physiology of solid tumors: opportunities (and problems) for cancer therapy. Cancer Res 1998, 58(7):1408.

35. Vaupel P, Kelleher DK, Höckel M: Oxygenation status of malignant tumors: pathogenesis of hypoxia and significance for tumor therapy. Semin Oncol 2001, 28(2 Suppl 8):29-35.

36. Sun X, Kanwar JR, Leung E, Vale M, Krissansen GW: Regression of solid tumors by engineered overexpression of von Hippel-Lindau tumor suppressor protein and antisense hypoxia-inducible factor-1alpha. Gene Ther 2003, 10(25):2081-2089.

37. Zhou H, Fei W, Bai Y, Zhu S, Luo E, Chen $K$, Hu J: RNA interferencemediated downregulation of hypoxia-inducible factor-1[alpha] inhibits angiogenesis and survival of oral squamous cell carcinoma in vitro and in vivo. Eur J Cancer Prev 2011, 2011. Publish Ahead of Print: 10.1097/ CEJ.1090b1013e32834dbbda.

38. Ali-Shtayeh MS, Yaniv Z, Mahajna J: Ethnobotanical survey in the Palestinian area: a classification of the healing potential of medicinal plants. J Ethnopharmacol 2000, 73(1-2):221-232.

39. Abu-Irmaileh BE, Afifi FU: Herbal medicine in Jordan with special emphasis on commonly used herbs. J Ethnopharmacol 2003, 89(2-3):193-197.

40. Sogno I, Vannini N, Lorusso G, Cammarota R, Noonan DM, Generoso L, Sporn MB, Albini A: Anti-angiogenic activity of a novel class of chemopreventive compounds: oleanic acid terpenoids. Recent Results Cancer Res 2009, 181:209-212.

41. Pfeffer U, Ferrari N, Morini M, Benelli R, Noonan D, Albini A: Antiangiogenic activity of chemopreventive drugs. Int J Biol Markers 2002, 18(1):70-74. 
42. Lamy E, Garcia-Käufer M, Prinzhorn J, Mersch-Sundermann V: Antigenotoxic action of isothiocyanate-containing mustard as determined by two cancer biomarkers in a human intervention trial. Eur J Cancer Prev 2012, 21(4):400-406.

43. Lorusso G, Vannini N, Sogno I, Generoso L, Garbisa S, Noonan DM, Albini A: Mechanisms of Hyperforin as an anti-angiogenic angioprevention agent. Eur J Cancer 2009, 45(8):1474-1484.

doi:10.1186/1472-6882-13-358

Cite this article as: Zihlif et al:: The antiangiogenic activities of ethanolic crude extracts of four Salvia species. BMC Complementary and Alternative Medicine 2013 13:358

\section{Submit your next manuscript to BioMed Central and take full advantage of:}

- Convenient online submission

- Thorough peer review

- No space constraints or color figure charges

- Immediate publication on acceptance

- Inclusion in PubMed, CAS, Scopus and Google Scholar

- Research which is freely available for redistribution 